\title{
Post-Sekulerisme Islam Populis di Indonesia
}

\author{
M. Mujibuddin, ${ }^{1}$ Rina Zuliana ${ }^{2}$ \\ ${ }^{1}$ Universitas Islam Negeri Sunan Kalijaga, Yogyakarta - Indonesia. ${ }^{2}$ Universitas Gadjah \\ Mada, Yogyakarta - Indonesia
}

\begin{abstract}
This article explores the phenomenology of post-secularism in Indonesia. Populist Islamic movement strike for islamization public sphere as a sign of post-secularism in Indonesia. The islamization proceeded both in government dan the public sphere. These phenomena show that the community of urban Muslims can't leave religious aspects in the public sphere. This research uses the qualitative-description method and library research models. The first result of this research shows that Islamic populism is coming from the urban Muslim middle class who have access to the modern world. Second, the populist Islamic movement who did islamization of the public sphere shows the strengthening of religion's role in the public sphere.
\end{abstract}

Tulisan ini menjelaskan fenomena post sekulerisme di Indonesia. Gerakan Islam populis yang memperjuangkan islamisasi ruang publik menjadi tanda adanya post-sekulerisme di Indonesia. Proses islamisasi ruang publik dilakukan baik dalam pemerintahan maupun di ruang publik. Penelitian ini menggunakan metode kualitatif-deskriptif dengan model studi pustaka. Penelitian ini menggunakan teori ruang publik Muslim. Hasil penelitian ini pertama menunjukkan bahwa islam populis lahir dari Muslim kelas menengah perkotaan yang memiliki akses lebih ke dunia modern. Kedua, Islamisasi ruang publik yang dilakukan oleh kelompok Islam populis menunjukkan bahwa adanya penguatan peran agama di ruang publik.

Keywords: post-secularism; the populist Islam; the Muslim public sphere

Korespondesi Penulis: M. Mujibuddin (mujibuddin79@gmail.com). Magister Aqidah dan Filsafat Islam Universitas Islam Negeri Sunan Kalijaga Yogyakarta, Indonesia 55281. 


\section{Pendahuluan}

Kemunculan gerakan Islam populis 212 memberikan warna baru bagi demokratisasi di Indonesia pasca reformasi. Gerakan Islam populis di Indonesia didominasi oleh Muslim kelas menengah perkotaan yang notabene memiliki akses lebih ke dunia modern. Kesadaran ini menunjukkan bahwa masyarakat modern di dunia ketiga tidak bisa melepaskan begitu saja agama di ruang publik. Hal ini berlawanan dengan pendapat August Comte. Menurut Comte di dalam dunia modern agama akan ditinggalkan oleh masyarakat. Namun realitas justru menunjukkan sebaliknya. Dalam kehidupan modern yang kompleks, masyarakat semakin haus terhadap nilai-nilai spiritualitas (Naim 2013).

Perkembangan dunia modern menyebabkan terjadinya perubahan besar dalam dunia pertanian, manufaktur, pertambangan, transportasi, dan teknologi serta memiliki dampak yang mendalam terhadap keadaan sosial politik, ekonomi, dan budaya masyarakat. Urbanisasi besarbesaran pun terjadi. Struktur sosial masyarakat pun juga berubah; dari yang semula petani menjadi karyawan pabrik. Perubahan struktur makro ini menyebabkan ada nilai-nilai religiusitas masyarakat yang hilang dan digantikan dengan rasionalitas dunia modern. Jika sudah demikian, maka yang terjadi adalah pergesaran dari masyarakat agamis menjadi masyarakat yang rasionalis, serta pembedaan mana urusan agama dan urusan dunia atau lebih dikenal dengan sekuler.

Akan tetapi di akhir abad ke-20 dan awal abad ke-21 keadaan menunjukkan sebaliknya. Kesadaran terkait dengan dunia modern yang tidak bisa menggantikan peran agama dalam sektor publik menyebabkan adanya perubahan pandangan terkait dengan sekulerisme. Menurut Habermas masyarakat dunia modern sedari awal memang tidak bisa melepaskan begitu saja terkait dengan agama. Sebab keadaran religius secara hakiki terkait erat dengan praksis hidup yang kontinu dalam sebuah kelompok, dan dengan kesadaran ini berarti agama memberi dorongan yang lebih kuat untuk membangun solidaritas (Menoh 2015: 104). Habermas juga menegaskan bahwa agama memainkan peran penting bagi demokras sebagai latar belakang dan sumber motivasi. Dalam hal ini Habermas kemudian berbicara terkait masyarakat post sekuler (Menoh 2015: 104). Fenomena masyarakat post-sekuler menunjukkan bahwa masyarakat modern yang ditandai dengan rasionalitas tinggi, kehidupan yang sekuler, namun dalam fenomena tersebut agama tidak bisa ditinggalkan. Masyarakat modern, terutama di Muslim perkotaan, tidak bisa meninggalkan agama.

Di dalam perjalanan demokrasi di Indonesia, pergulatan hubungan antara agama dan negara sudah sulit untuk dibedakan lagi. Adanya dominasi agama dalam ruang publik, terutama agama Islam, menjadi bukti nyata bahwa batasan antara hubungan keduanya semakin kabur. Syariatisasi Peraturan Daerah (Perda) dan pergulatan wacana selama 10 tahun terakhir membuktikan kalau agama tidak bisa dilepaskan begitu saja dari ruang publik. Justru yang terjadi adalah sebaliknya, bahwa antar kelompok Islam saling berkontestasi untuk merebut wacana keislaman dalam ruang publik (Kersten 2016: 245).

Pengkaburan batasan di ruang publik ini semakin terlihat jelas pada saat pemilu DKI Jakarta 
2017. Setahun sebelumnya, kita bisa melihat banyaknya massa aksi yang terlibat di dalamnya. Secara garis besar, keadaan pada saat itu ialah bagaimana peran agama memiliki potensi besar dalam mempengaruhi ruang publik. Fenomena seperti itu memperlihatkan dengan begitu jelas bahwa agama sudah tidak memiliki batasan dalam ruang publik. Pengaruh agama pada saat itu sudah terlampau jauh sehingga batasan itu sudah tidak ada lagi. Bahasa agama yang seharusnya bisa diterima oleh publik namun justru menunjukkan intervensinya kepada negara. Padahal ruang publik yang didefinisikan sebagai ruang yang netral dan terbebas dari intervensi agama maupun politik, namun justru dimanfaatkan untuk mengintervensi satu sama lain. Ruangruang publik sudah dikonstruksi dengan berbagai intervensi dari kelompok-kelompok Islam. Di berbagai media sosial, media cetak, atau media lainnya juga tidak lepas dari intervensi agama. Kebijakan-kebijakan Pemerintah pun juga disasar dengan dalih syariatisasi Perda. Dalam kasus Pilkada DKI nampak jelas bagaimana ruang publik ini sudah diintervensi oleh gerakangerakan Islam. Fenomena ini kemudian disebut oleh Dale F. Eicklemen dan Jon W. Anderson sebagai ruang publik Muslim.

Inilah yang kemudian menjadi bukti bahwa gerakan-gerakan Islam telah memasuki era postsekuleris. Terdapat beberapa ciri yang mengindikasikan hal tersebut. Pertama, gerakan-gerakan Islam mampu merasionalisasikan bahasa agama menjadi bahasa publik, sehingga terdapat kekuatan tersendiri ketika hal itu masuk dalam ruang publik. Kedua, gerakan-gerakan ini lahir dari kesadaran Muslim kelas menengah per- kotaan yang notabennya merasakan arus modernisasi, namun mereka tidak meninggalkan agama sebagaimana sekulerisasi yang terjadi di dunia Barat.

Dengan adanya fenomena tersebut, maka dalam penelitian ini penulis hendak menekankan bagaimana fenomena post-sekuleris terjadi pada gerakan-gerakan Islam pasca Orde Baru, khususnya pasca Pilkada DKI Jakarta. Pengambilan problem ini tidak hanya terkait pada trajectory gerakan Islam pasca Orde Baru yang didominiasi oleh gerakan post-Islamisme, akan tetapi melampaui hal tersebut, fenomena-fenomena politik Islam ini menunjukkan bahwa telah terjadi postsekulerisasi yang dirasakan oleh uamt Islam. Oleh karenanya, upaya yang dilakukan oleh gerakan-gerakan Islam selanjutnya ialah bagaimana merangkul sebanyak massa untuk mengikuti ideologi dan cita-cita yang dimiliki oleh kelompok tersebut.

Penelitian terdahulu yang terkait dengan kajian ini di antaranya adalah; Pertama, buku Gusti A. B. Menoh (2015) yang berjudul Agama dalam Ruang Publik: Hubungan Antara Agama dan Negara dalam Masyarakat Postsekuler Menurut Jurgen Habermas. Buku ini menjelaskan bagaimana Habermas terkait dengan harmonisasi antara agama dan negara, terutama dalam konteks masyarakat modern. Pandangan postsekuleris yang ditunjukkan dalam buku ini mengacu pada konsep berketuhanan dalam Pancasila. Menurutnya, Pancasila merupakan sebuah terobosan untuk mengharmonisasikan peran agama dan negara. Kedua, artikel yang ditulis oleh Otto Gusti Madung (2016) "Toleransi dan Diskurus Post-Sekulerisme". Dalam tulisan 
ini Madung menjelaskan bagaimana saat ini masyarakat Indonesia sudah memasuki era postsekulerisme. Hal ini ditandai dengan semakin menguatnya peran agama dalam ruang publik.

Ketiga, artikel yang ditulis oleh Irfan Noor (2012) "Identitas Agama, Ruang Publik dan PostSekulerisme: Perspektif Diskursus Jurgen Habermas." Dalam tulisan ini, Irfan menjelaskan bahwa diferensiasi fungsional dalam masyarakat modern yang mendorong ke arah individualisasi agama tidak secara niscaya mengimplikasikan hilangnya pengaruh dan relevansi agama di ruang publik. namun demikian, agama juga memiliki batasan ketika hendak berkontestasi dalam ruang publik. batasan itu adalah bahasa agama harus diterjemahkan terlebih dahulu ke dalam bahasa yang mudah diterima oleh publik, yaitu memiliki status episteme yang dapat diterima oleh warga atau umat beragama lainnya.

Dengan melihat tulisan-tulisan di atas, penulis belum menemukan titik tekan pada aspek kelas menengah perkotaan, khsususnya pada umat Muslim. Penekanan terhadap umat Islam ini didasarkan atas semakin meluasnya peranan agama Islam dalam ruang publik, baik dalam lembaga pemerintahan maupun gerakan sosial. Maka dari itu, letak perbedaan dengan penelitian ini adalah pada aspek gerakan Islam pasca reformasi hingga pilkada DKI Jakarta. Hal ini didasarkan pada perkembangan dinamika gerakan Islam pasca reformasi yang semakin massif bergerak di ruang publik, baik di pemerintahan maupun dalam gerakan sosial. Di samping itu juga, gerakan-gerakan Islam yang berkembang selama dekade terakhir ini terdiri dari masyarakat kelas menengah perkotaan, yang notabene nya memiliki akses lebih ke dunia modern, sehingga penulis berasumsi bahwa masyarakat kelas menengah perkotaan merupakan masyarakat yang telah termodernkan namun tidak bisa meninggalkan unsur agama, dan bahkan agama dijadikan sebagai penguat identitas keberagamaannya.

Metode penelitian dalam tulisan ini menggunakan metode kualitatif-deskriptif dengan model studi pustaka dan observasi. Model pengumpulan data yang dilakukan dalam penelitian ini dengan cara meneliti sejumlah buku, artikel, laporan penelitian, jurnal, disertasi, serta melakukan pencarian di internet dan media cetak yang berhubungan dengan tulisan ini. Adapun sumber rujukan yang diambil ada dua yaitu sumber primer dan sumber sekunder. Sumber primer yang digunakan dalam penelitian ini ialah buku, buku, atau sumber lainnya yang terkait dengan post-sekuler dan Islam populis di Indonesia. Sedangkan sumber sekundernya terkait dengan gerakan Islam di Indonesia.

Untuk mendukung dalam menganisis penelitian ini, penulis akan menggunakan perspektif ruang publik Muslim. Sebuah teori yang terinspirasi dari ruang publiknya Habermas namun dengan perspektif yang berbeda. Ruang publik Muslim di artikan sebagai ruang yang diciptakan oleh kelompok-kelompok Islam dengan mengusung tema-tema syariah, baik secara langsung maupun tidak langsung.Ruang publik Muslim dibangun oleh para intelektual atau ulama terkait pembangunan pemahaman mereka tentang Islam dengan melintas batasanbatasan kultural yang semuanya dimungkinkan memanfaatkan teknologi media baru, termasuk 
memvisualisasikan gagasan itu sebagai bagian dari strategi dakwah Islam (Eickelman dan W. Anderson 2003:1-20). Hal ini kemudian berujung pada adanya penekanan Islam sebagai pengatur tatanan sosal yang di dalamnya melibatkan banyak aspek, di antaranya ialah ulama dan syariah. Syariah sebagai tatanan sosial yang otonom serta peran komunitas dalam ruang publik. Marshall Hodgson mencatat terdapat tiga isu sentral dalam menyatukan umat di wilayah perkotaan. Pertama, hukum syariah; kedua, yayasan waqaf; ketiga, sufi atau tarekat (Hoexter, Eisenstadt, dan Levtzion 2002: 10).

Umat dan syariah merupakan konsepsi sentral dalam memahami ruang publik Muslim juga menjadi penanda adanya politik umat Islam. Konsepsi ini kemudian melahirkan sebuah konsensus (ijma') yang memiliki kekuatan pengubah tatanan sosial masyarakat. Hal ini bisa saja mendistorsi peraturan pemerintah yang kemudian digantikan dengan ijma. Bahkan hasil ijma ini kemudian bisa juga bisa menjadi dasar hukum untuk menentukan arah kebijakan sebuah pemerintah. Dengan demikian, apa yang dihasilkan dalam ijma tersebut berkaitan erat dengan adanya syariah. Syariah merupakan sebuah peraturan yang mengatur hidup umat Islam. Syariah ini kemudian menjadi tawaran untuk merubah tatanan masyarakat sesuai dengan nilai dan norma dalam Islam (Hoexter et al. 2002:11).

\section{Post-Sekulerisme Islam di Indonesia}

Post sekuler mengandaikan bahwa agama memiliki peran penting dalam kehidupan masyarakat. Bukti dari pentingnya agama dalam ruang publik adalah pada aspek moral. Moralitas publik tidak bisa digantikan begitu saja dengan rasionalitas dunia modern. Moralitas merupakan unsur tradisionalis yang lahir dari budaya maupun agama. Misalnya orang yang hendak aborsi dilarang karena di dalam kandungannya itu adalah manusia. Jika pelarangan ini hanya didasarkan pada moral rasional, maka hal itu akan cacat epistemologi. Akan tetapi, jika pelarangan tersebut bersumber dari moralitas agama yang melarang untuk membunuh manusia, maka hal itu lebih masuk akal. Menurut Habermas, persoalan lain yang diakibatkan oleh modernitas berupa individualisme, disintegrasi sosial, benturan antar peradaban, penggunaan teknologi yang menghancurkan kehidupan umat manusia tidak dapat diselesaikan oleh modernitas sendiri (Menoh 2015: 106). Oleh karena itu, di dalam dunia modern yang sekuler tidak bisa begitu saja hanya didasarkan pada aspek rasionalitas semata tanpa unsur agama, dan agama tidak bisa begitu saja ditinggalkan atau hanya menjadi urusan individu.

Dengan melihat krisis yang diakibatkan oleh dunia sekuler, Habermas melihat bahwa agama memiliki potensi untuk memperbaiki moralitas publik. Ia menambahkan moral sekuler dari asalusulnya tidak terintegrasi dalam suatu praksis bersama. Sebaliknya kesadaran religius secara hakiki terkait erat dengan praksis hidup yang kontinu dalam sebuah kelompok atau persekutuan. Agama bukan serta merta hanya sistem nilai, akan tetapi agama juga merupakan pandangan dunia. Karena itu, agama di dalam agama ditemukan isi kognitif dan kekuatan motivasi yang tidak ada dalam pandangan dunia yang profan (Menoh 2015:108). 
Indonesia merupakan negara yang memiliki keragaman agama dan budaya. Struktur dan sistem masyarakat Indonesia tidak bisa dilepaskan dari kedua unsur tersebut. Meskipun dunia modern telah masuk di Indonesia, akan tetapi eksistensi agama dalam ruang publik tidak bisa ditinggalkan. Kuatnya religiusitas masyarakat Indonesia menjadi faktor penting dalam menahan proses sekulerisasi dalam ruang publik. Tesis yang mengatakan bahwa sekulerisasi akan terjadi di masyarakat perkotaan dirasa gagal ketika melihat fenomena religiusitas masyarakat perkotaan Indonesia.

Meskipun demikian, dunia modern yang mengusung gagasan sekulerisasi tidak terlalu diminati oleh masyarakat perkotaan. Masyarakat Indonesia yang sejak dulu dikenal dengan tradisi, agama, dan budaya begitu kuat mempengaruhi keberadaan dunia modern. Ketika dunia dunia modern tidak menawarkan sebuah sistem nilai dan norma yang sepadan dengan agama, maka masyarakat perkotaan akan kembali lagi ke agama.

Kelas menengah perkotaan yang berasal dari interaksi dengan dunia modern tidak selalu menghilangkan agama dalam ruang privat maupun publik. Dalam pengamatan Vatikiotis ia menjelaskan bahwa di Indonesia, kebangkitan kembali kepada semangat keagamaan tahun 1980-1990an adalah fenomena khas kelas menengah di wilayah-wilayah perkotaan merupakan segmen masyarakat yang paling banyak tersentuh oleh pembangunan ekonomi dan perubahan sosial. Fenomena ini berpengaruh luas pada meningkatnya ketaatan beragama orang-orang Islam yang sedang menikmati kemakmuran sebagai kelas menengah (Vatikiotis 1996:152-3). Lantas kenapa kemakmuran yang ditawarkan oleh dunia modern dan adanya proses sekulerisasi justru malah meningkatkan ketaatan beragama. Hal ini dikarenakan adanya gempuran perubahan sosial yang sangat cepat. Vatikiotis kemudian menambahkan bahwa terjadi gejala diskolasi sosial yang menginggap masyarakat. Banyak orang yang kemudian kembali pada agamanya untuk memperteguh diri sebagai reaksi atas hancurnya tatanan nilai moral sosial tradisional yang terjadi di sekitar mereka (Vatikiotis 1996:153).

Kelompok Muslim kelas menengah perkotaan adalah gugus baru dalam struktur sosial masyarakat Indonesia yang paling cepat mendapatkan pengaruh globalisasi dan modernisasi, dan di sisi lain paling berpengaruh dalam narasi nasional Indonesia (Wildan 2016:196). Oleh karena itu, Muslim kelas menengah perkotaan bersinggungan secara langsung dengan modernitas dan mengenali apa saja yang tidak ada di dalamnya. Seperti yang di singgung di atas bahwa dunia modern tidak bisa menggantikan norma agama, oleh karenanya meskipun masyarakat perkotaan hidup di dunia modern mereka tidak akan meninggalkan dunia agama. Melihat kekosongan dunia modern maka masyarakat perkotaan nampak terjadi peningkatan kesalehan dalam beragama. Kesalehan ini terlihat dari simbolsimbol agama yang digunakan, mengikuti tren ustadz-ustadz, sehingga hal itu kemudian membentuk identitas kolektif kelompok tersebut.

Sikap dan perilaku kesalehan masyarakat Muslim perkotaan ditujukan untuk proses islamisasi. Mulai dari islamisasi televisi yang berisi 
ceramah-ceramah setiap hari, islamisasi budaya -yang sebenarnya merupakan proses arabisasi-, misalnya mengenakan baju khas Arab baik yang digunakan oleh laki-laki atau perempuan, karena anggapan mereka dengan menggunakan seperti itu akan meningkatkan kesalehannya. Dalam hal ini Ariel Heryanto (2014) menjelaskan bahwa islamisasi dalam layar kaca di Indonesia semakin nampak ketika era reformasi bergulir. Ia mencotohkan terkait dengan film Ayat-Ayat Cinta yang diambil dari novelis Indonesia Habiburrahman El-Syirazi menyita banyak penonton. Hal ini menunjukkan bagaimana konstruksi kesalehan masyarakat perkotaan tidak hanya terjadi dalam hal politik belaka melainkan juga dalam ranah budaya.

Proses Islamisasi di era modern berlangsung tidak hanya melalui tatap muka, seperti pengajian, akan tetapi juga bisa melalui media. Pertumbuhan media di era saat ini tidak bisa dilepaskan dari dunia modern. Peran media kemudian tidak hanya untuk alat komunikasi semata, melainkan juga menyebarkan ide dan gagasan. Pada tahun 2000 ke atas, media memunculkan ustadz-ustadz di televisi untuk mengisi ceramah-ceramah. Kemunculan fenomena ini menjadi tanda bahwa dunia modern justru menjadi peluang bagi para da'i untuk memberikan ceramah-ceramah di media televisi. Di saat dunia modern telah memberikan kemudahan untuk berkomunikasi melalui jaringan media dan internet, para da'i kemudian memanfaatkan perangkat dunia modern untuk kegiatan berceramah.

Kegiatan tersebut kemudian berlanjut ketika internet dan media sosial mulai banyak digunakan oleh masyarakat. Da'i-dai'i yang sebelumnya telah sering muncul di televisi nasional kemudian menyebar ke media-media sosial lainnya seperti youtube.com, instagram, dan media sosial lainnya. Dampaknya adalah mereka semakin dikenal luas oleh masyarakat Indonesia, terutama masyarakat Muslim perkotaan. Di samping itu juga, keberadaan internet memudahkan mereka membuat wadah bagi umat Islam untuk bertanya tentang persoalan yang dihadapi oleh umat Islam. Pasar yang dituju adalah kelas menengah perkotaan yang notabene tidak memiliki banyak waktu untuk mencari ilmu karena disibukkan dengan hiruk pikuk dunia modern. Sebagai dampaknya, mereka kemudian mencari waktu bersama untuk mengaji dengan mendatangkan ustadz-ustadz yang sedang naik daun di layar kaca Indonesia, atau terkenal melalui media sosial lainnya.

Para ustadz-ustadz ini juga membuka dialog dengan tidak bertemu dalam satu tempat. Media dan internet dimanfaatkan untuk membuka dialog kepada para jamaah untuk berkomunikasi. Masyarakat diperbolehkan menanyakan semua hal tentang kehidupannya, bahkan tidak jarang dari mereka yang kemudian menanykan sebuah hukum atau fatwa terkait dengan satu persoalan yang sedang dihadapinya. Persoalan yang muncul kemudian adalah siapa yang memberikan legitimasi bagi para da'i yang memberikan fatwa hukum kepada para jamaahnya? Ini lah yang dirisaukan oleh Nadirsyah Hosen, selaku dosen hukum, yang mempertanyakan maraknya fenomena jual beli fatwa di media (Fealy and White 2012).

Meningkatnya pengaruh media dalam mengkonstruksi masyarakat dalam hal ini disebut dengan fenomena post-truth. Di era pascakebenaran ini, media memiliki peran penting 
dalam mengkonstruksi pemahaman agama masyarakat perkotaan. Di era post-truth ini juga media menjadi komoditas baru dan sebagai daya tawar kepada masyarakat Muslim perkotaan. Media akan membuat konten semenarik mungkin untuk memancing minat masyarakat. Segala yang dapat menarik minat masyarakat ditayangkan melalui media dengan model-model ideal, yang mudah dipahami dan diterima, sehingga batas antara kebenaran dan simulasi menjadi campur aduk. Dalam konteks inilah hyperreality tercipta. Dunia hyperreality menunjukkan adanya ketidakjelasan antara kebenaran dan kenyataan, dunia hyperreality dipenuhi oleh duplikasi realitas melalui media (Baudrillard 2008). Menurut Lechte, munculnya realitas baru yang diakibatkan oleh reproduksi sempurna dari suatu objek, yang diwakili oleh kode-kode yang telah merasuk dalam sendisendi kehidupan masyarakat modern, sehingga mampu mem-baypass sesuatu yang real (Lechte 2001: 352).

Maka dari itu, adanya fenomena post-truth dan dominasi media telah mengaburkan makna realitas. Jadi seakan-akan kebenaran sebuah agama di media menjadi kebenaran yang real dari sebuah pemahaman agama itu sendiri. Konstruksi yang dibuat oleh media dan diterima oleh masyarakat menjadi suatu kebenaran, memperkuat tesis bahwa saat ini dunia modern tidak bisa melepaskan agama dan menggagalkan proses sekulerisasi di dunia modern.

\section{Gerakan Sosial Post-Sekuleris di Indonesia}

Fenomena post-sekulerisme di Indonesia ditandai dengan adanya penolakan atas sekulerisasi dalam kehidupan sehari-hari. Kuatnya agama dan budaya masyarakat Indonesia telah membuat sekulerisasi tersebut gagal. Meskipun demikian, proses modernisasi yang terjadi di masyarakat Indonesia berlangsung cukup baik, dibuktikan dengan adanya penerimaan dan pemanfaatan instrument dunia modern. Sebagaimana yang telah dijelaskan di atas, media dan internet menjadi alat modern yang banyak digunakan oleh masyarakat Muslim Indonesia, khususnya kelas menengah perkotaan. Kondisi seperti ini didukung oleh lingkungan masyarakat perkotaan yang cenderung individualis sebagai akibat dari modernitas dan kapitalis. Kondisi seperti ini kemudian dimanfaatkan oleh segenap tokoh agama untuk mengisi kekosongan moral yang diakibatkan oleh dunia modern.

Untuk mengisi kekosongan yang diakibatkan oleh dunia modern, kelompok Muslim kelas menengah perkotaan tidak hanya bergerak mengisi media saja, melainkan juga bergerak dalam bidang sosial-politik. Demokratisasi yang berlangsung pasca jatuhnya rezim Orde Baru telah memberi ksempatan bagi para aktivis islamis untuk memperjuangkan aspirasi dan citacita politiknya. Berbagai organisasi Islam bermunculan setelah rezim Orde Baru muncul. Keadaan seperti ini wajar terjadi mengingat gerakan Islam di masa Orde Baru telah dibungkam, dan aspirasi politiknya hanya terpusat pada satu partai saja. Oleh karena itu, di era Reformasi kesempatan politik pun terbuka untuk menyuarakan aspirasi dan cita-cita politik Islam yang selama ini mati suri di era Orde Baru.

Di era Reformasi kelompok underground memanfaatkan momen ini untuk membuat sebuah organisasi Islam non-mainstream. Kelompok-kelompok tersebut ialah Front Pem- 
bela Islam (FPI), Partai Keadilan (saat ini Partai Keadilan Sejahtera), Front Umat Islam (FUI), Majelis Mujahidin Indonesia (MMI), Hizbut Tahrir Indonesia (HTI), FPIS, Forum Komunikasi Ahlusunnah Wal Jamaah (FKAW) (Abidin 2015:134). Meskipun gerakan-gerakan tersebut memiliki cita-cita yang berbeda-beda, akan tetapi kemunculan dan cita-citanya secara umum tidak berada dalam arus mainstream wacana pemikiran mayoritas Islam Indonesia, dalam hal ini diwakili oleh NU dan Muhammadiyah.

Kemunculan gerakan di atas memiliki persamaan cita-cita yaitu adanya formalisasi syariat Islam di ruang publik, baik dengan merubah Indonesia menjadi negara Islam atau pemberlakuan Perda syariat. Menurut Nazih Ayubi (Basyir 2016) gerakan Islam ini disebut Muslim politik (political islamist) dan Muslim kultural (cultural islamist). Bactiar Effendi mencatat kecenderungan Muslim politik di tandai dengan alasan bahwa Islam harus menjadi dasar negara; syariah harus diterima dalam konstitusi negara karena kedaulatan politik ada di tangan Tuhan. Konsep negara-bangsa yang ada di Indonesia dirasa tidak sesuai dengan apa yang di syariatkan dalam Islam karena masih mengenal batas kedaerahan. Oleh karenanya gerakan tersebut ingin mengganti sistem negara-bangsa dengan konsep ummah. Konsep ummah ini mengandaikan tidak adanya batasan geografik antar umat Islam.

Pada saat Reformasi bergulir, kelompokkelompok tersebut mengadakan sebuah aksi besar di masa presiden Megawati Soekarno Putri. Tema yang diusung dalam demonstrasi tersebut ialah menyerukan untuk kembali Piagam Jakarta dan penerapan syariat Islam. Mereka mendapat momentum pada sidang MPR pada tahun 2000 untuk memasukkan agenda Piagam Jakarta dalam Amandemen UUD 1945, namun gagal di tengah jalan. Akan tetapi mereka tidak menyerah di situ saja, usaha-usaha terus dilakukan dalam menerapkan hukum syariat Islam di berbagai daerah seperti Sulawesi Selatan, Jawa Barat, dan daerah-daerah lainnya (Nashir 2007). Meskipun pada saat itu banyak pengamat yang menduga bahwa Islam akan terpinggirkan karena ada dunia modern yang ditandai dengan industrialisasi dan rasionalisasi, namun yang terjadi justru sebaliknya. Demokratisasi di masa Reformasi memberi kesempatan politik bagi kelompok tersebut untuk memperjuangkan pemberlakuan peraturan daerah berbasis syariah atau sistem islam.

Michael Buehler mengatakan bahwa politisi dari partai sekuler menjadi salah aktor dibalik perumus, pengadopsi dan penerapan perdaperda syariah. Secara konkrit Buehler mencatat terdapat 7 dari 33 provinsi dan 51 dari sekitar 510 kabupaten mengadopsi sekurangnya satu perda syariah mulai tahun 1999 hingga 2009 (Buehler 2011). Hal ini menjadi bukti tentang bagaimana islamisasi ruang publik itu dilakukan oleh kelompok-kelompok Islam baik secara kultural maupun struktural. Islamisasi ini kemudian mengaburkan makna sistem demokrasi yang notabennya tidak memandang jumlah mayoritas minoritas, akan tetapi proses tersebut lama kelamaan menggeser paradigm menjadi mayoritarianisme. Umat Islam yang mayoritas dianggap memiliki power untuk menguasai ruang-ruang strategis, misalnya, untuk pemberlakuan perda syariah dan Islamisasi ruang publik. 
Gerakan umat Islam ini kemudian berlanjut pada saat Pilkada DKI Jakarta. Aksi demonstrasi yang dilakukan oleh umat Islam sejak tahun 2016 lalu didominasi oleh masyarakat Muslim perkotaan. Sebelumnya, aksi ini terjadi akibat adanya anggapan bahwa Basuki Tjahaja Purnama (Ahok) telah melakukan penodaan agama terhadap umat Islam di Kepulauan Seribu. Dalam kasus ini media, sebagai representasi era modern, memiliki andil besar dalam membentuk opini publik, apalagi pemberitaannya ditambahi dengan hal-hal yang bersifat provokatif, sehingga orang dengan mudah terpengaruh oleh adanya berita tersebut.

Gerakan yang diinisiasi oleh Gerakan Nasional Pengawal Fatwa-MUI (GNPF-MUI) 'berhasil' menarik massa begitu banyak. Rangkaian aksi pun dilakukan dengan rentang waktu yang berbeda-beda. Misalnya Aksi Bela Islam pada tanggal 4 bulan November (ABI 411), tanggal 2 Desember (ABI 212), gerakan shalat subuh berjamaah, dan gerakan-gerakan lainnya. Bagi sebagaian kalangan, adanya gerakangerakan tersebut diistilahkan sebagai gerakan populis (Hadiz 2016). Gerakan-gerakan tersebut yang awalnya hanya ingin memberhentikan Ahok dari kursi gubernur, namun pada saat cuti menjelang Pilkada, Aksi Bela Islam masih terus dilakukan. Padahal pada saat itu Ma'ruf Amin, selaku ketua MUI, sudah menginstruksikan bahwa sudah tidak diperlukan lagi gerakan semacam itu, sebab apa yang diinginkan telah tercapai (Bonasir 2017). Meskipun demikian, para alumni gerakan 212 tetap menggelar beberapa pertemuan untuk memperingati aksi yang pernah dilakukan. Pertemuan pada tanggal
2 Desember 2017, dan pertemuan pada tanggal 2 Desember 2018 Kapitra Ampera, mengatakan:

"untuk mengkonsolidasikan umat Islam sehingga menimbulkan kesadaran agar memilih pemimpin, baik kepala daerah maupun di legislatif melalui pemilu maupun pilpres di eksekutfi melalui pemilihan presiden untuk memilih umat Islam yang berkualitas memimpin Republik ini, memimpin daerah dan memimpin DPR. Dan ini politik." (Bonasir 2017).

Aksi 411 dan 212 merupakan kesempatan bagi Front Pembela Islam (FPI) dan kelompok lainnya untuk menunjukkan eksistensinya di era modernisasi dan demokratisasi. FPI selama ini dipandang sebagai organisasi di luar mainstream Islam Indonesia mampu mencuri panggung dalam hingar-bingar perpolitikan nasional. Habib Rizieq, selaku ketua umum FPI, yang juga dikatakan sebagai ulama pinggiran namun saat ini Habib Rizieq menjadi tokoh sentral dalam gerakan Islam. Habib Rizieq, FPI, dan GNPF-MUI merupakan motor penggerak berlangsungnya berbagai aksi di Jakarta. Tema yang diusung tidak hanya untuk menurunkan Ahok dari kursi gubernur, melainkan jauh lebih besar, yaitu bagaimana ruang dan wacana publik dikuasai oleh gerakan Islamisme. Dengan memenangkan perang wacana publik, maka proses islamisasi ruang publik akan berjalan sesuai rencana. Hal ini bisa dilihat dari proyeksi FPI dalam pemberlakuan syariat Islam di pemerintahan. Sejak mula FPI berdiri hingga hari ini, keinginannya untuk mensyariatisasi peraturan daerah tak kunjung surut.

Adanya kasus Ahok hanya dijadikan alat untuk memepersatukan umat yang kemudian dikendalikan oleh FPI untuk menegakkan syariat 
Islam di ruang publik. Terbukti setelah adanya gerakan-gerakan tersebut banyak ruang-ruang publik kemudian hanya dikuasai oleh kalangan tertentu, sehingga hal itu berdampak pada tidak adanya akses bagi kelompok lainnya. Di sisi lain, kemenangan ini bagi FPI merupakan momentum penting untuk berpartisipasi dalam perpolitikan di Indonesia. Meskipun FPI tidak memiliki partai sendiri dan tidak berafiliasi dengan partai apapun, akan tetapi membangun jaringan dengan penguasa yang mendukung aspirasi umat Islam. Oleh karena itu, pada saat aksi tersebut FPI sebenarnya juga tidak menyepakati dan merestui jika Ahokmenjadi gubernur lagi.

Gerakan-gerakan Islam yang lahir di era Pilkada DKI Jakarta tidak berhenti ketika Ahok gagal menjadi gubernur saja. Selang beberapa waktu kemudian gerakan Islam 212 ikut serta dalam pilpres 2019. Pada mulanya gerakan ini dilanda kebimbangan apakah harus mendukung Ma'ruf Amin selaku calon wakil Presiden dari Joko Widodo atau mendukung Prabowo-Sandi. Pada tanggal 29 Juli 2018 alumni 212 mengadakan pertemuan yang dinamakan Ijtihad Ulama untuk merekomendasikan calon presiden yang didukung. Pada mulanya rekomendasi yang dihasilkan dalam Ijtihad Ulama tersebut adalah pasangan Prabowo-Salim Segaf dan PrabowoUstaz Abdul Somad. Rekomendasi pasangan ini ingin melengkapi porsi nasionalis-religius. Akan tetapi, dinamika politik tidak sama dengan persoalan umat. Dari kedua calon yang direkomendasikan oleh Ijtihad Ulama, Prabowo dan partai koalisinya justru memilih Sandiaga Uno sebagai calon wakilnya. Padahal Sandiaga Uno baru saja terpilih menjadi wakil Gubernur Jakarta, namun
Sandiaga meninggalkan jabatan tersebut untuk menemani Prabowo menjadi calon wakil presidennya.

Meskipun demikian, pada akhirnya gerakan Islam 212 kemudian juga menyepakati dipilihnya Sandiaga Uno sebagai calon presiden untuk mendampingi Prabowo. Untuk mengisi posisi dari kalangan religius, Sandiaga kemudian diberi predikat sebagai santri post-islamisme. Sandi yang notabennya sebagai pengusaha juga pernah mengenyam pendidikan pesantren kilat, dengan begitu Sandi juga layak dikatakan sebagai santri. Akan tetapi, hal itu tidak cukup untuk meraih suara rakyat Indonesia. Strategi lainnya ialah dengan mengikutsertakan Habib Rizieq untuk memberikan komando untuk memilih pasangan Prabowo-Sandi. Dengan keikutsertaan Habib Rizieq, diharapkan mampu mendulang suara dari rakyat Indonesia seperti yang pernah dilakukan pada masa Pilkada DKI Jakarta.

Setelah melalui pergolakan panjang, akhirnya Alumni 212 kemudian mengadakan Ijtihad Ulama II dan melahirkan 17 poin Pakta Integritas yang ditanda tangani oleh Prabowo (Rosana and Chairunnisa 2018).

Adapun 17 Pakta Integritas tersebut adalah: 1) Sanggup melaksanakan Pancasila dan UUD 1945 secara murni dan konsekuen; 2) Siap menjaga dan menjunjung nilai-nilai religius dan etika yang hidup di tengah masyarakat; 3) Berpihak pada kepentingan rakyat dalam setiap proses pengambilan kebijakan dengan memperhatikan prinsip representasi, proporsionalitas, keadilan, dan kebersamaan; 4) Memperhatikan kebutuhan dan kepentingan umat beragama, baik umat Islam, maupun umat agama-agama lain 
yang diakui pemerintah Indonesia untuk menjaga persatuan nasional; 5) Sanggup menjaga dan mengelola Ukhuwah Islamiyah (Persaudaraan Umat Islam) secara adil untuk menciptakan ketentraman dan perdamaian di tengah kehidupan masyarakat Indonesia; 6) Menjaga kekayaan alam nasional untuk kepentingan sebesar-besar kemakmuran rakyat Indonesia; 7) Menjaga keutuhan wilayah NKRI dari ancaman separatisme dan imperialisme; 8) Mendukung perjuangan kemerdekaan Palestina di berbagai panggung diplomatik dunia sesuai dengan semangat dan amanat Pembukaan UUD 1945; 9) Siap menjaga amanat TAP MPRS No. 25/1966 untuk menjaga NKRI dari ancaman komunisme serta pahampaham yang bisa melemahkan bangsa dan negara lainnya; 10) Siap menjaga agama-agama yang diakui pemerintah Indonesia dari tindakan penodaan, penghinaan, penistaan serta tindakantindakan lain yang bisa memancing munculnya ketersinggungan atau terjadinya konflik melalui tindakan penegakan hukum sesuai peraturan perundang-undangan yang berlaku; 11) Siap melanjutkan perjuangan reformasi untuk menegakkan hukum secara adil tanpa pandang bulu kepada segenap warga negara; 12) Siap menjamin hak berserikat dan berkumpul dan menyatakan pendapat secara lisan dan tulisan; 13) Siap menjamin kehidupan yang layak bagi setiap warga negara untuk dapat mewujudkan kedaulatan pangan, ketersediaan sandang dan pangan; 14) Siap menyediakan anggaran yang memprioritaskan pendidikan umum dan pendidikan agama secara proporsional; 15) Menyediakan alokasi anggaran yang memadai untuk penyelenggaraan kesehatan rakyat dan menjaga kelayakan pelayanan rumah sakit baik peme- rintah maupun swasta; 16) Siap menggunakan hak konstitusional dan atribut yang melekat pada jabatan Presiden untuk melakukan proses rehabilitasi, menjamin kepulangan, serta memulihkan hak-hak Habib Rizieq Shihab sebagai warga negara Indonesia, serta memberikan keadilan kepada ulma, aktivis 411, 212, dan 313 yang pernah/sedang mengalami proses kriminalisasi melalui tuduhan tindakan yang pernah disangkakan penegakan keadilan juga perlu dilakukan terhadap tokoh-tokoh lain yang mengalami penzaliman; 17) Menghormati posisi ulama dan bersedia untuk mempertimbangakan pendapat para ulama dan pemuka agama lainnya dalam memecahkan masalah yang menyangkut kemaslahatan kehidupan berbangsa dan bernegara.

\section{Kesimpulan}

Dunia modern yang identik dengan wacana sekulerisasi telah terbukti gagal. Proses modernisasi yang membawa wacana pemisahan antara agama dan negara tidak terjadi di Indonesia. Hal ini juga merupakan sebuah kritik atas tesis yang diberikan oleh August Comte bahwa masyarakat modern akan menghilangkan agamanya dalam ruang publik. Tesis ini kemudian diperkuat oleh Weber dan dikritik oleh Habermas bahwa dunia modern tidak menawarkan perangkat yang lahir dari agama. Nilai dan norma sosial yang selama ini lahir dari agama tidak mampu diciptakan oleh dunia modern. Akibatnya, masyarakat modern akan kembali ke agama untuk mengisi ruangruang kosong yang tidak ada dalam dunia modern. Inilah yang disebut sebagai post-sekuler. Masyarakat post-sekuleris yang dimaksud oleh Habermas adalah masyarakat yang tidak bisa meninggalkan agamanya dalam dunia modern. 
Post-sekuler yang terjadi dalam masyarakat modern terlihat dalam kelompok Islam populis. Melalui berbagai Aksi Bela Islam yang dikomandoi oleh GNPF-MUI, sebagian umat Islam melakukan aksi besar-besara di Jakarta untuk menurunkan dan memenjarakan Ahok dari kursi gubernur. Dengan memanfaatkan bahasa publik, gerakan Islam ini kemudian mampu mengundang ratusan ribu umat untuk ikut demonstrasi. Hal ini menunjukkan bahwa nalar publik Muslim ini sudah dikuasai oleh kelompok Islam untuk mewujudkan kepentingannya. Nalar publik yang seharusnya netral terhadap intervensi agama atau negara justru dimanfaatkan oleh segenap kelompok Islam untuk menguasai wacana publik. Mengingat bahwa negara Indonesia mayoritas Islam, hal ini menjadi peluang bagi kelompok Islam untuk membahasakan nalar agamanya dalam bahasa publik.

Produksi wacana dengan bahasa publik yang dilakukan oleh kelompok Islam populis menjadi bukti nyata bahwa masyarakat Islam tidak bisa menanggalkan agamanya ketika berhadapan dengan modernitas. Mereka justru memanfaatkan dunia modern untuk menyebarkan ide dan gagasan dengan bahasa publik yang mudah dipahami oleh khalayak umum. Hal ini merupakan sebuah upaya Islamisasi yang dilakukan oleh gerakan Islam untuk menguasai ruang publik. Sebagai bukti adanya upaya Islamisasi ini adalah dengan adanya pemberlakuan Perda Syariah di berbagai kab/kota atau provinsi, dan Islamisasi dalam bentuk budaya seperti busana baik laki-laki maupun perempuan. Dengan demikian, gerakan Islam memanfaatkan nalar publik untuk mewujudkan proses islamisasi ruang publik.]

\section{Daftar Pustaka}

Abidin, Zaenal. 2015. "Wahabisme, Transnasionalisme dan Gerakan-gerakan Radikal Islam di Indonesia." Tasamuh 12(2):130-48.

Basyir, Kunawi. 2016. "Ideologi Gerakan Politik Islam di Indonesia." Al-Tahrir: Jurnal Pemikiran Islam 16(2):339-362.

Baudrillard, Jean. 2008. Fatal Strategies. New York: Semiotext.

Bonasir, Rohmatin. 2017. "Dengan 212, Umat Islam 'Ingin Berkuasa Lewat Pilkada, Pemilu dan Pilpres."' Bbc.Com. Retrieved (https://www.bbc.com/indonesia/indone sia-42184928).

Buehler, Michael. 2011. "Partainya Sekuler, Aturannya Syariah - Liputan Khusus 10 Tahun Perda Syariah." Tempo, 74-75.

Eickelman, Dale F. dan Jon W. Anderson. 2003. New Media in the Muslim World: The Emerging Public Sphere. Indiana: Indiana University Press.

Fealy, Greg and Sally White. 2012. Ustadz Seleb, Bisnis Moral dan Fatwa Online: Ekspresi Islam Kontemporer. Jakarta: Komunitas Bambu.

Hadiz, Vedi R. 2016. Islamic Populism in Indonesia and the Middle East. Cambridge: Cambridge University Press.

Heryanto, Ariel. 2014. Identity and Pleasure: The Politics of Indonesian Screen Culture. Singapore: National University of Singapore (NUS) Press. 
Hoexter, Miriam, Shmuel N. Eisenstadt, and Nehemia Levtzion, eds. 2002. The Public Sphere in Muslim Societies. Albany: State University of New York Press.

Kersten, Carool. 2016. Islam in Indonesia: The Contest for Society, Ideas and Values. London: Hurst \& Company.

Lechte, John. 2001. 50 Filsuf Kontemporer; Dari Strukturalisme Sampai Posmodernitas. terj. A. G. Admiranto. Yogyakarta: Kanisisus.

Madung, Otto Gusti. 2016. "Toleransi dan Diskursus Post-Sekularisme." Jurnal Ledalero: Wacana Iman dan Kebudayaan 15(2):305322.

Menoh, Gusti A. B. 2015. Agama dalam Ruang Publik: Hubungan Antara Agama dan Negara dalam Masyarakat Postsekuler Menurut Jurgen Habermas. Yogyakarta: Kanisius.

Naim, Ngainun. 2013. "Kebangkitan Spiritualitas Masyarakat Modern." Kalam 7(2):237-58.
Nashir, Haedar. 2007. Gerakan Islam Syariat: Reproduksi Salafiyah Ideologis di Indonesia. Jakarta: PSAP Muhammadiyah.

Noor, Irfan. 2012. "Identitas Agama, Ruang Publik dan Post-Sekulerisme: Perspektif Diskursus Jurgen Habermas." Jurnal Ilmiah Ilmu Ushuluddin 11(1):61-87.

Rosana, Francisca Christy and Ninis Chairunnisa. 2018. "17 Poin Pakta Integritas Ijtima Ulama II yang Disetujui Prabowo." Tempo.Co. Retrieved January 11, 2019 (https://nasional.tempo.co/read/112704 8/17-poin-pakta-integritas-ijtima-ulamaii-yang-disetujui-prabowo).

Vatikiotis, Michael R. J. 1996. Political Change in Southeast Asia: Trimming the Banyan Tree. London: Routledege.

Wildan, Muhammad. 2016. "Aksi Damai 411212, Kesalehan Populer, dan Identitas Muslim Perkotaan Indonesia." Maarif 11(2):188-202. 